\title{
Factors Affecting Auditor Independence in Tunisia: The Perceptions of Financial Analysts
}

\author{
Omri Mohamed Ali ${ }^{1}$, Akrimi Nesrine ${ }^{2, ~ * ~}$ \\ ${ }^{1}$ Accounting Department at College of Business Administration- Northern Border University-Arar, Saudi Arabia \\ ${ }^{2}$ Faculty of Economics and Management Sciences - Tunis El Manar University-Tunis, Tunisia
}

Email address:

medomri@gmail.com (M. A. Omri), nesrine.akrimi.othmani@gmail.com (N. Akrimi)

\section{To cite this article:}

Omri Mohamed Ali, Akrimi Nesrine. Factors Affecting Auditor Independence in Tunisia: The Perceptions of Financial Analysts. Journal of Finance and Accounting. Vol. 3, No. 3, 2015, pp. 42-49. doi: 10.11648/j.jfa.20150303.12

\begin{abstract}
The purpose of this paper is to explore the perceptions of Tunisian financial analysts regarding factors influencing auditor independence. Our study examines the impact of 49 independence enhancing and threatening factors on the perceptions of 54 financial analysts using a questionnaire instrument. The results indicate that the principal threat factors relate to non audit services provision by the incumbent auditor and the existence of personal and financial relationships. The principal enhancement factor is the positive reputation. Exploratory factor analysis reduces the factors to a small number of dimensions. The most important dimension identified is the economic dependence and existence of personal and financial relationships.
\end{abstract}

Keywords: Auditor Independence, Financial Analysts, Factors, Perceptions

\section{Introduction}

External auditor independence has been the topic matter of academic and professional debate in developed and developing countries (Hamuda \& Sawan, 2014).

In recent time, auditor independence has become more examined given the financial and accounting scandals.

These scandals have led to the introduction of new laws relating to the strengthening of financial relations.

A law called "Sarbanes-Oxley" was adopted in 2002 by the United States, the law focuses on corporate governance and the role of leaders in this governance (Wang et al., 2010).

At the French legislation, there are several new regulations on financial security. We mention in particular the Financial Security Act of August 1, 2003.

In Tunisia the regulatory framework has been strengthened by Law no: 2005-96 of 18 October 2005. This law represents for the Tunisian legislator prevention to the occurrence of financial scandals such as the case of the group Batam end of 2002.

These legislative changes whose main purpose is to ensure the reliability of financial and accounting information underline the importance attached to the audit quality in general and auditor independence in particular.

Auditor independence has been analyzed based on two dimensions, that is, fact and appearance Alleyne et al. (2006).
According to Beattie et al. (1999) "Since third parties are unable to observe directly independence in fact the appearance of independence assumes prime importance".

Studies in this area have concentrated upon the determination of factors which influence independence and evaluate their impact upon perceived independence. These factors have been the subject of examination and pronouncements by policy makers for several decades (Beattie et al., 1999).

The aim of this paper is to explore financial analysts' perceptions of factors influencing auditor independence in Tunisia.

The results of this research are expected to contribute to the debate on auditor independence by assessing the issue in the context of an emerging market, i.e. Tunisia.

Our study can also inform policy makers and professional accounting bodies as to how auditing and accounting standards can be structured to assure suitable regulation of the capital market.

This paper is structured as follows. The next section sets out the theoretical framework and reviews the relevant prior literature. Research methodology section explains the methods used. Results and discussion section provides findings and analysis. A final section summarizes by setting out conclusions. 


\section{Theoretical Framework and Literature Review}

Auditor independence is defined by Gay and Simnett (2003) as "ability to withstand pressure from management influence when conducting an audit or providing audit-related servces, so that the professional integrity of the auditor is not compromised".

Auditor independence has been analyzed based on two dimensions, that is fact and appearance.

According to Alleyne et al. (2006)"independence in fact refers to the actual objective state of the relationship between auditing firms and their clients. Independence in appetence refers to the subjective state of that relationship as perceived by clients and third parties".

The preponderance of auditor independence both in fact and appearance is generally approved in theory and practice.

Thus, a review of the relevant prior literature is exposed in this section.

According to Jensen and Meckling (1976), information asymmetry exists between agents who have additional information about the company and principal.

This results in the weak controlling power of the shareholders and gives managers an opportunity to maximize their profits. Accordingly, the shareholders of the company hire an auditor to produce information that is later used in concluding a contract with the agent (Watts \& Zimmerman,
1986).

Thus, auditing is perceived as a method to minimize the agency costs (Al AjmietSaudagaran, 2011). This can be attained exclusively when auditor is actually independent in both fact and appearance.

Though, the auditor has to serve three major types of conflicts of interest which can compromise his independence.

According to role conflict theory, the auditor is required to control the company's financial statements and the public expects the auditor reliably fulfill that role.

Goldman and Barlev (1974) states that conflicts arise between:

- Auditors and firms

- Owners and managers

- Auditors 'own economic motives and audit criteria

Therefore, auditor independence may be compromised when conflicting interests arise as to what is the audit's role (Alleyne et al., 2006).

Ben Saad and Lesage (2008) referred to the attribution theory to analyze the perception of external auditor independence. These authors state that, according to this theory, the auditor's independence can be explained by factors. These factors can be internal and external.

Several studies have sought to determine the factors that may influence auditor independence in appearance

The following table reports a relevant review of by distinguishing independence factors in four categories:

Table 1. Previous study on factors influencing auditor independence in appearance.

\begin{tabular}{|c|c|c|c|c|}
\hline \multirow{2}{*}{ Category } & \multirow{2}{*}{ Factors } & \multirow{2}{*}{ Author(s) } & \multicolumn{2}{|c|}{ Impact on independence in appearance } \\
\hline & & & + & - \\
\hline \multirow{6}{*}{ Auditors depêndant factors } & Competence & Prat-DitHauret (2003) & + & \\
\hline & & Blokdijik\&al. (2006) & Big size & Small size \\
\hline & Audit firm size & Abu Bakar\& Ahmad (2009) & + & \\
\hline & & Al-Sawalqa\&Qtish (2012) & + & - \\
\hline & Reputation & $\begin{array}{l}\text { Chan et al. (1993) } \\
\text { Al Ajmi\&Saudagaran (2011) }\end{array}$ & + & \\
\hline & Ethics & Prat-DitHauret(2003) & + & \\
\hline \multirow{3}{*}{ Auditee dependent factors } & Existence ofan audit committe & $\begin{array}{l}\text { Alleyne et al.(2006) } \\
\text { Al-Sawalqa\&Qtish (2012) }\end{array}$ & + & \\
\hline & Strono financial condition & Bell \&al. (2001) & & \\
\hline & Strong inancial condition & Prat-Dit Hauret (2003) & - & \\
\hline \multirow{10}{*}{$\begin{array}{l}\text { Factors depending on the } \\
\text { auditor and on the auditee }\end{array}$} & & Ghosh\& Moon (2005) & + & \\
\hline & Auditors rotation & Daniels et Booker (2011) & + & \\
\hline & & Abu Bakar et al. (2005) & & \\
\hline & Non audit services & Salehieral. (2009) & - & \\
\hline & & Dart (2011) & & \\
\hline & Personal and financial relationship & Hussey (1999) & & \\
\hline & Economic denendence & Adeyemi et Akinniyi (2012) & - & \\
\hline & Economic dependence & Abu Bakar et $a l$. (2005) & - & \\
\hline & Disclosure of financial relationshins & Beattie et al. (1999) & + & \\
\hline & Disciosure or inancial relationsnips & Al-Ajmi\&Saudagaran (2011) & + & \\
\hline \multirow{8}{*}{$\begin{array}{l}\text { Auditor or auditeenon } \\
\text { dependent factors }\end{array}$} & & Jeong\&al. (2005) & & \\
\hline & Audit market competition & Abu Bakar\&al. (2005) & - & \\
\hline & & Salehi et al. (2009) & & \\
\hline & & Beattie \&al. (1999) & & \\
\hline & Liability regime & Prat-Dit Hauret (2003) & + & \\
\hline & & Matsumura\& Tucker (1995) & & \\
\hline & External reviews & Prat-Dit Hauret (2003) & + & \\
\hline & & Beattie et al. (1999) & & \\
\hline
\end{tabular}




\section{Methodology}

Our study uses the methodology developed by Alleyne et al. (2006) and Al-AjmietSaudagaran (2011).

The research method employed in this study is the quantitative questionnaire. According to Alleyne et al. (2006), the literature has revealed that the dominant method of research was the quantitative questionnaire. The questionnaire was chosen because “inferences about people's attitudes and opinions can be elicited most effectively and efficiently by survey methods"' (Beattie et al., 1999).

As the main users of financial statements, financial analysts were the sample selected for investigation. A questionnaire was developed and directly distributed in February and March 2014 to 105 Tunisian financial analysts working on behalf stock brokers. 53 usable questionnaires were collected from with different profile types (Age, experience, specialty, diploma). This yields a response rate of 50, $48 \%$.

The survey focused on 49 audit-related issues drawn from audit literature and Tunisian accounting and audit regulation.

The questionnaire used in the study was divided into five sections: section 1 concern background information including experience, age, size of audit firm, size of company...

Section 2 dealt with auditors dependant factors including factors related to competence, audit firm size, reputation and ethics.

Section 3 focused on auditee dependent factors including factors related to the existence of audit committee and strong financial condition.

Section 4 concerned factors depending on the auditor and the auditee including factors related to auditor's rotation, non audit services, personal and financial relationship, economic dependence and disclosure of financial relationship.

Section 4 focused on auditor or auditeenon dependent factors including factors related to audit market competition, liability regime and external reviews.

Table 2 shows the 49 factors of the study.

Table 2. List of factors affecting auditor independence.

\begin{tabular}{|c|c|}
\hline Description & Factors \\
\hline \multirow{3}{*}{ Audit firm size } & A non Big4 firm \\
\hline & Small local firm \\
\hline & Being a sole practitioner \\
\hline \multirow{4}{*}{ Auditor competence } & Auditor is qualified as a chartered accountant \\
\hline & Auditor has 5 years or more audit experience \\
\hline & Auditor has a good knowledge of audit and accounting standards \\
\hline & Auditor has a prior experience as an accountant in the industry \\
\hline Auditor reputation & The name of auditor has not been quoted in relation with fraudulent affaires \\
\hline \multirow{6}{*}{ Ethics } & Auditor does not commit a professional misconduct outside of his audit mission \\
\hline & Auditor does not commit a personnel misconduct outside of his audit mission \\
\hline & Auditor complies with hispersonal tax obligations \\
\hline & The concern to complete theaudit mission within the time-limits \\
\hline & Introduction of internal ethical chartby audit firm \\
\hline & Auditor complies with his commitments towards third parties \\
\hline \multirow{4}{*}{ Existence of an audit committee } & Existence of an audit committee composed of independent directors \\
\hline & Existence of an active audit committee \\
\hline & Existence of an independent and competentaudit committee \\
\hline & The bigger size of theaudit committee \\
\hline \multirow{2}{*}{ Strong financial condition of the audited company } & High degree of liquidity \\
\hline & High degree of profitability \\
\hline \multirow{6}{*}{ Economic dependence } & Auditor's income depends on the retention of a specific audit client \\
\hline & $\geq 10 \%$ of total auditor revenues from one client \\
\hline & Auditor perceives income other than those provided by law \\
\hline & Auditor perceives excessive fees compared to total income \\
\hline & Client important to firm's overall portfolio \\
\hline & Directors' de facto control of auditors' remuneration \\
\hline \multirow{2}{*}{ Personal and financial relationships } & The auditor is a shareholder of the auditee \\
\hline & The existence of a family relationship between the auditor and auditee \\
\hline \multirow{5}{*}{ Provision ofnon audit services } & Non audit services $\geq 100 \%$ audit fees \\
\hline & Non audit services $\geq 50 \%$ audit fees \\
\hline & Non audit services $\geq 25 \%$ audit fees \\
\hline & Preparation of financial statements \\
\hline & Provision of executive search and appointment services by incumbent auditor \\
\hline
\end{tabular}




\begin{tabular}{ll}
\hline Description & Factors \\
\hline \multirow{2}{*}{ Auditor rotation } & Rotation of audit partners \\
& Rotation of audit firms \\
Disclosure of financial relationships & Disclosure of audit fees \\
& Disclosure of non audit fees \\
& Disclosure of non audit services \\
External reviews & Joint audit \\
& Partner review \\
Competition & External control \\
Liability regime & High level of Competition among audit firms \\
Flexibility & Audit fee discounting and low balling \\
\hline
\end{tabular}

Financial analysts were expected to indicate the extent to witch each of these issues affected auditor independence in appearance. Their responses were in the form of a five point Likert type scale:

- Seriously undermined independence

- Slightly undermined independence

- No effect on independence

- Slightly enhanced independence

- Seriously enhanced independence

Our study uses a framework of auditor independence in appearance which includes independence threatening and independence enhancing factors. This study addresses the issue of auditor independence by analyzing the perceptions of financial analysts.

To assure that the questionnaire was comprehensible a pilot test was conducted the questionnaire was sent to three financial analysts and two academics there were asked to complete the questionnaire and to submit suggestions for improvements.

\section{Results and Discussion}

Table 3 sets outthe mean scores (column 2) and ranks (columns 3 and 4)are of 49 factors on the appearance of independence. The 49 factors are divided into two categories. Category 1 includes the factors which financial analysts believe to impair auditor independence (mean score <3). Category 2 includes the factors which financial analysts believe to enhance independence (mean score $>3$ ).

Factor scores were significantly different from 3 at the 5\% level (using t-test).

Table 3. Perceptions of financial analysts regarding factors affecting auditor independence.

\begin{tabular}{|c|c|c|c|}
\hline Factors & MeanScore & RUa & REb \\
\hline A non Big4 firm & 1,4151 & & 13 \\
\hline Being a sole practitioner & 1,3774 & & 10 \\
\hline Small local firm & 1,3775 & & 11 \\
\hline High degree of liquidity & 2,3962 & & 17 \\
\hline High degree of profitability & 2,3962 & & 17 \\
\hline Rotation of audit partners & 4,4717 & 9 & \\
\hline Rotation of audit firms & 4,7358 & 2 & \\
\hline Penalty regime & 4,717 & 3 & \\
\hline Auditors has a positive reputation & 4,7547 & 1 & \\
\hline The name of auditor has not been quoted in relation with fraudulent affaires & 4,7547 & 1 & \\
\hline Disclosure of audit fees & 4,2264 & 11 & \\
\hline Disclosure of non audit fees & 4,2642 & 10 & \\
\hline Disclosure of non audit services & 3,8679 & 12 & \\
\hline Non audit services $\geq 100 \%$ audit fees & 1,0755 & & 1 \\
\hline Non audit services $\geq 50 \%$ audit fees & 1,2264 & & 6 \\
\hline Non audit services $\geq 25 \%$ audit fees & 1,717 & & 16 \\
\hline Provision of executive search and appointment services by incumbent auditor & 1,1887 & & 5 \\
\hline Preparation of financial statements & 1,1132 & & 2 \\
\hline The auditor is a shareholder of the auditee & 1,2642 & & 8 \\
\hline The auditor is an employee of the auditee & 1,1698 & & 4 \\
\hline The auditor obtains interest free loan from the auditee & 1,1698 & & 4 \\
\hline The existence of a family relationship between the auditor and auditee & 1,1509 & & 3 \\
\hline Flexibility of accounting standards & 1,3774 & & 10 \\
\hline Auditor does not commit a professional misconduct outside of his audit mission & 3,6038 & 15 & \\
\hline Auditor does not commit a personnel misconduct outside of his audit mission & 3,5849 & 16 & \\
\hline Auditor complies with hispersonal tax obligations & 3,6415 & 14 & \\
\hline The concern to complete theaudit mission within the time-limits & 3,3208 & 20 & \\
\hline Introduction of internal ethical chartby audit firm & 3,3208 & 20 & \\
\hline Observance of professional secrecy & 3,283 & 22 & \\
\hline Auditor complies with his commitments towards third parties & 3,717 & 13 & \\
\hline
\end{tabular}




\begin{tabular}{|c|c|c|c|}
\hline Factors & MeanScore & RUa & REb \\
\hline Auditor's income depends on the retention of a specific audit client & 1,3962 & & 12 \\
\hline$\geq 10 \%$ of total auditor revenues from one client & 1,4906 & & 15 \\
\hline Auditor perceives income other than those provided by law & 1,283 & & 9 \\
\hline Auditor perceives excessive fees compared to total income & 1,2453 & & 7 \\
\hline Client important to firm's overall portfolio & 1,2453 & & 7 \\
\hline Directors' de facto control of auditors' remuneration & 1,2453 & & 7 \\
\hline Joint audit & 4,6792 & 4 & \\
\hline External control & 4,6415 & 5 & \\
\hline High level of Competition among audit firms & 1,4151 & & 13 \\
\hline Audit fee discounting and low balling & 1,434 & & 14 \\
\hline Auditor is qualified as a chartered accountant & 3,3019 & 21 & \\
\hline Auditor has 5 years or more audit experience & 3,4906 & 19 & \\
\hline Auditor has a good knowledge of audit and accounting standards & 3,5283 & 17 & \\
\hline Auditor has a prior experience as an accountant in the industry & 3,5094 & 18 & \\
\hline Existence of an active audit committee & 4,6038 & 6 & \\
\hline Existence of an independent and competentaudit committee & 4,566 & 7 & \\
\hline The bigger size of theaudit committee & 3,3208 & 20 & \\
\hline
\end{tabular}

RUa: mean rank of the undermining factor

$\mathrm{REb}$ : mean rank of the enhancing factor

\subsection{Threatening Factors}

Out of the 49 factors, financial analysts perceived 24 factors as undermining auditor independence.

Small audit firm: to test he impact of the size of audit firm on auditor independence three factors are included in the questionnaire. Financial analysts perceive them as threatening factors. They rank them as 13th, 10th and 11th.

These results are similar to those reported by Al-AjmietSaudagaran (2011).

Provision of non audit services: Five factors are included in this study to test the impact of non audit services on auditor independence. Three of the factors are associated to the size of the non audit services fees and two other factors are related to the type of services. The five factors are classified by our sample among the factors that impair independence. Financial analysts rank provision of non audit services by incumbent auditors in excess of $100 \%$ of audit fees as the first serious factor that impair independence.

Economic dependence: Six factors representing economic dependence of the auditor on the auditee are included in the questionnaire. The financial analysts perceive them as threatening factors. Surprisingly, economic dependence is not selected by our respondents among their most critical factors.

\subsubsection{Strong Financial Condition of the Audited Company}

Two factors representing strong financial condition of the audited company are included in the questionnaire. Financial analysts perceive them as threatening factors. The two factors are ranked 17 thby our respondents.

\subsubsection{Existence of Financial and Personal Relationships}

The three factors representing existence of financial and personal relationships are highly ranked among threatening factors. These factors are: the auditor is an employee of the auditee (4th), the auditor obtains interest free loan from the auditee (4th) and the existence of a family relationship between the auditor and auditee (3th).

\subsubsection{Competition Among Audit Firms}

High level of competition among audit firms and audit fee discounting and low baling are ranked by financial analysts as 13 th and 14 th respectively among threatening factors.

\subsubsection{Flexibility}

Financial analysts perceive that flexibility of accounting standards as one of the threatening factors to ao auditor independence. It is ranked 10th by our sample.

\subsection{Enhancing Factors}

Out of the 49 factors, our respondents perceived 25 factors as enhancing auditor independence.

\subsubsection{Competence}

Four factors are included in this survey to test the influence of competence on auditor independence. These factors do not appear high in the rankings indicating that the importance of these factors enhancing independence is minimal.

\subsubsection{Auditor Rotation}

Rotation of audit firms is ranked by Tunisian financial analysts at number two among the factors enhancing independence. Regarding the second factor "rotation of audit partners", our respondents ranked it 9th relative to other enhancing factors.

\subsubsection{Liability Regime}

Financial analysts attached highest importance to this factor. they ranked it 3 th relative to other enhancing factors.

\subsubsection{Existence of Audit Committee}

Among factors identified as enhancers of auditor independence, financial analysts attached highest importance to three factors related to the existence of audit committee. These factors are ranked 8th, 6th and 7 th relative to other enhancing factors. 


\subsubsection{Reputation}

Factors related to the reputation were perceived as the strongest factors enhancing independence. The two factors measuring reputation were ranked by financial analysts at number one among factors enhancing independence.

\subsubsection{Ethics}

Four factors representing ethicswere ranked near the bottom by financial analysts indicating that the importance of these factors enhancing auditor independence was minimal. The other factors related to ethics were ranked low by our sample.

\subsubsection{External Reviews}

Financial analysts rank highest factors related to the external reviews. Joint audit is ranked in 4th position. Partner review is ranked in 7 th position and external control is ranked in 5 th position.

Most results are consistent with those reported by beattie et al. (1999), alleyne et al. (2006) et Al-Ajmi et Saudagaran (2011).

\subsubsection{Disclosure of Financial Relationships}

Financial analysts ranked factors related to disclosure of financial relationships near the bottom, indicating that the importance of these factors enhancing independence is minimal

\subsection{Factor Analysis}

Many of the factors presented in our study are expected to be highly correlated. In an attempt to identify the critical dimensions of auditor independence, a factor analysis using principal components method with Varimax rotation was performed.

The final dimensions are extracted for each group using the eigenvalue $\geq 1$. For our sample, 13 dimensions have been extracted witch explain $85,903 \%$ of the variance among the independence factors. These factors are described in Table 4. All component factors with loadigs $\geq|0,5|$ are presented together with factor loadings.

The top extracted factors are

- Economic dependence and existence of personal and financial relationships $(16,32 \%)$

- Ethics $(14,19 \%)$

- Competence $(10,523 \%)$

- Competition and flexibility of accounting standards $(8,87 \%)$

\section{Conclusion}

This research investigates perceptions regarding auditor independence held by 54 Tunisian financial analysts using a questionnaire.

The influence of a large set of 49 factors on auditor independence in appearance is investigated.

Results show that a wide range of factors have a significant impact upon auditor independence. Specifically, 24 factors are found to have a significant negative impact on auditor independence in appearance. In addition, 25 factors are found to have a significant positive impact on independence.

According to Tunisian financial analysts, the principal threat factors relate to provision of non audit services and the existence of personal and financial relationships.

The results also indicate that the principal enhancement factor is related to positive reputation.

The 49 factors are reduced using factor analysis to a smaller number of uncorrelated dimensions (13 dimensions). The four most important dimensions being: Economic dependence and existence of personal and financial relationships, ethics, Competence, Competition and flexibility of accounting standards.

Overall, our survey has revealed the complexity of the independence concept.

Our findings should be of direct interest to policy-makers. In particular, this research's results can assist both Tunisian policy-makers in the setting up of a common core of independence standards, and can assist Tunisian policy-makers in their evaluation of the influence of recent regulatory changes.

This survey has several limitations. First, it explores the perceptions of the factors influencing auditor independence of only one category of users of financial statements. Other users such as shareholders and bank loan officers are not covered in this research.

Second, data are collected using a survey questionnaire. This method is subject to certain sorts of bias, such as the response bias which may affect the reliability of the answers.

Future research can focus on conducting more in-depth research investigating the underlying reasons for financial analysts' perceptions of auditor independence.

\section{Appendix}

Dimensions identified using principal component extraction and Varimax rotation

\begin{tabular}{|c|c|c|c|c|c|c|c|c|c|c|c|c|c|}
\hline \multicolumn{14}{|c|}{ Matrice des composantes après rotationa } \\
\hline & \multicolumn{13}{|c|}{ Composante } \\
\hline & 1 & 2 & 3 & 4 & 5 & 6 & 7 & 8 & 9 & 10 & 11 & 12 & 13 \\
\hline A non Big4 firm & & & & & $\begin{array}{l}, 92 \\
5\end{array}$ & & & & & & & & \\
\hline Being a sole practitioner & & & & & $\begin{array}{l}94 \\
9\end{array}$ & & & & & & & & \\
\hline Small local firm & & & & & $\begin{array}{l}94 \\
9\end{array}$ & & & & & & & & \\
\hline
\end{tabular}




\begin{tabular}{|c|c|c|c|c|c|c|c|c|c|c|c|c|c|}
\hline \multicolumn{14}{|l|}{ Matrice des composantes après rotationa } \\
\hline & \multicolumn{13}{|c|}{ Composante } \\
\hline & 1 & 2 & 3 & 4 & 5 & 6 & 7 & 8 & 9 & 10 & 11 & 12 & 13 \\
\hline $\begin{array}{l}\text { Auditor is qualified as a chartered } \\
\text { accountant }\end{array}$ & & &, 836 & & & & & & & & & & \\
\hline $\begin{array}{l}\text { Auditor has } 5 \text { years or more audit } \\
\text { experience }\end{array}$ & & & ,945 & & & & & & & & & & \\
\hline $\begin{array}{l}\text { Auditor has a good knowledge of audit } \\
\text { and accounting standards }\end{array}$ & & & ,960 & & & & & & & & & & \\
\hline $\begin{array}{l}\text { Auditor has a prior experience as an } \\
\text { accountant in the industry }\end{array}$ & & & ,954 & & & & & & & & & & \\
\hline Auditors has a positive reputation & & & & & & & & & ,908 & & & & \\
\hline $\begin{array}{l}\text { The name of auditor has not been quoted } \\
\text { in relation with fraudulent affaires }\end{array}$ & & & & & & & & & ,913 & & & & \\
\hline $\begin{array}{l}\text { Auditor does not commit a professional } \\
\text { misconduct outside of his audit mission }\end{array}$ & &, 885 & & & & & & & & & & & \\
\hline $\begin{array}{l}\text { Auditor does not commit a personnel } \\
\text { misconduct outside of his audit mission }\end{array}$ & & ,912 & & & & & & & & & & & \\
\hline $\begin{array}{l}\text { Auditor complies with hispersonal tax } \\
\text { obligations }\end{array}$ & &, 822 & & & & & & & & & & & \\
\hline $\begin{array}{l}\text { The concern to complete theaudit } \\
\text { mission within the time-limits }\end{array}$ & &, 750 & & & & & & & & & & & \\
\hline $\begin{array}{l}\text { Introduction of internal ethical chartby } \\
\text { audit firm }\end{array}$ & & ,786 & & & & & & & & & & & \\
\hline $\begin{array}{l}\text { Observance of professional secrecy } \\
\text { Auditor complies with his commitments } \\
\text { towards third parties }\end{array}$ & & ,670 & & & & & & & & & & & \\
\hline $\begin{array}{l}\text { Existence of an audit committee } \\
\text { composed of independent directors }\end{array}$ & & & & & & &, 806 & & & & & & \\
\hline Existence of an active audit committee & & & & & & &, 858 & & & & & & \\
\hline $\begin{array}{l}\text { Existence of an independent and } \\
\text { competentaudit committee }\end{array}$ & & & & & & &, 816 & & & & & & \\
\hline The bigger size of theaudit committee & & & & & & &, 512 & & & & & & \\
\hline High degree of liquidity & & & & & & & & ,956 & & & & & \\
\hline $\begin{array}{l}\text { High degree of profitability } \\
\text { Auditor's income depends on the } \\
\text { retention of a specific audit client }\end{array}$ &, 767 & & & & & & & ,956 & & & & & \\
\hline $\begin{array}{l}\geq 10 \% \text { of total auditor revenues from one } \\
\text { client }\end{array}$ & ,604 & & & & & & & & & & & & \\
\hline $\begin{array}{l}\text { Auditor perceives income other than } \\
\text { those provided by law }\end{array}$ & ,933 & & & & & & & & & & & & \\
\hline $\begin{array}{l}\text { Auditor perceives excessive fees } \\
\text { compared to total income }\end{array}$ & ,952 & & & & & & & & & & & & \\
\hline \multirow[t]{3}{*}{$\begin{array}{l}\text { Client important to firm's overall } \\
\text { portfolio }\end{array}$} & ,926 & & & & & & & & & & & & \\
\hline & Comp & sante & & & & & & & & & & & \\
\hline & 1 & 2 & 3 & 4 & 5 & 6 & 7 & 8 & 9 & 10 & 11 & 12 & 13 \\
\hline $\begin{array}{l}\text { Directors' de facto control of auditors' } \\
\text { remuneration }\end{array}$ &, 898 & & & & & & & & & & & & \\
\hline $\begin{array}{l}\text { The auditor is a shareholder of the } \\
\text { auditee }\end{array}$ & ,676 & & & & & & & & & & & & \\
\hline The auditor is an employee of the auditee &, 760 & & & & & & & & & & & & \\
\hline $\begin{array}{l}\text { The auditor obtains interest free loan } \\
\text { from the auditee }\end{array}$ &, 760 & & & & & & & & & & & & \\
\hline $\begin{array}{l}\text { The existence of a family relationship } \\
\text { between the auditor and auditee }\end{array}$ & 810 & & & & & & & & & & & & \\
\hline Non audit services $\geq 100 \%$ audit fees & & & & & & & & & & & & &, 551 \\
\hline Non audit services $\geq 50 \%$ audit fees & & & & & & & & & & & & &, 829 \\
\hline Non audit services $\geq 25 \%$ audit fees & & & & & & & & & & & & & ,615 \\
\hline $\begin{array}{l}\text { Provision of executive search and } \\
\text { appointment services by incumbent } \\
\text { auditor }\end{array}$ & & & & & & & & & &, 784 & & & \\
\hline Preparation of financial statements & & & & & & & & & &, 824 & & & \\
\hline Rotation of audit partners & & & & & & & & & & &, 851 & & \\
\hline Rotation of audit firms & & & & & & & & & & &, 851 & & \\
\hline Joint audit & & & & & &, 851 & & & & & & & \\
\hline Partner review & & & & & &, 817 & & & & & & & \\
\hline External control & & & & & &, 832 & & & & & & & \\
\hline
\end{tabular}




\begin{tabular}{|c|c|c|c|c|c|c|c|c|c|c|c|c|c|}
\hline \multicolumn{14}{|l|}{ Matrice des composantes après rotationa } \\
\hline & \multicolumn{13}{|c|}{ Composante } \\
\hline & 1 & 2 & 3 & 4 & 5 & 6 & 7 & 8 & 9 & 10 & 11 & 12 & 13 \\
\hline Penalty regime & & & & & & 558 & & & &,- 519 & & & \\
\hline $\begin{array}{l}\text { High level of Competition among audit } \\
\text { firms }\end{array}$ & & & & ,902 & & & & & & & & & \\
\hline $\begin{array}{l}\text { Audit fee discounting and low balling } \\
\text { Flexibility of accounting standards }\end{array}$ & & & & $\begin{array}{l}, 919 \\
929\end{array}$ & & & & & & & & & \\
\hline Disclosure of audit fees & & & & & & & & & & & & ,928 & \\
\hline Disclosure of non audit fees & & & & & & & & & & & & ,901 & \\
\hline Disclosure of non audit services & & & & & & & & & & & &, 575 & \\
\hline
\end{tabular}

Méthode d'extraction: Analyse en composantes principales.

Méthode de rotation :Varimax avec normalisation de Kaiser.

\section{References}

[1] Abu Bakar, N., \& Ahmad, M., (2009) "Auditor independence: Malaysian accountants perceptions", International journal of business and management, vol.4, $\mathrm{N}^{\circ} 12$, pp.129-141.

[2] Abu Bakar, N., Abdul Rahman, A., \& Abdul Rashid, H., (2005), "Factors influencing auditor independence: Malaysian loan officers' perceptions", Managerial Auditing Journal, vol 20, $\mathrm{pp}, 804-822$.

[3] Adeyemi, S.B., \&Olowookere, J, K., (2012), "Non audit services and auditor independence", Business and Management Review, vol.2, $\mathrm{N}^{\circ} 5$, pp.89-97.

[4] Al-Ajmi, J., \&Saudagaran, S., (2011), "Perceptions of auditors and financial statements users regarding auditor independence in Bahrain" , Managerial Accounting Journal, vol.26,N²,pp.130-160

[5] Alleyne,P.A., Devonish, D., \&Alleyne, P., (2006), "Perceptions of auditors independence in Barbados", Managerial Accounting Journal, vol.21, $\mathrm{N}^{\circ} 6$, pp.621-635.

[6] Al Sawalqa, F., Qtish, A., (2012), “ Jordanian shareholders' perception of external auditor independence", Interdisciplinary Journal of Comtemporary Research in Business, vol.4,N²,pp.626-633.

[7] Beattie,V., Brandt,R., \&Fearneley,A., (1999), " Perceptions of auditor independence : U.K Evidence”, Journal of International Accounting, Auditing and taxation, vol.8, $\mathrm{N}^{\circ} 1,67-107$.

[8] Bell T., Landsman W.R., \& Shackelford, D. A., (2001), "Auditors' Perceived Business Risk and Audit Fees: Analysis and Evidence", Journal of Accounting Research, vol.39, pp.35-43.

[9] Blokdijk,H., Drieenhuizen, F., Simunic,D.A., \&Stein,M., (2006), "An analysis of cross-sectional differences in Big and Non Big public accounting firms audit programs", Auditing : A journal of practice \& theory, vol.25, pp.27-48.

[10] Ben Saad, E., Lesage, C. (2008). "Auditor's independence: What does really matter? A proposalfor an independence system". European Accounting Association, Rotterdam, Netherland

[11] Chan,P., Ezzamel,M., \&Gwilliam, D., (1993), “ Determinants of audit fees for quoted UK companies", Journal of Business Finance \& Accounting", vol.20, $\mathrm{N}^{\circ} 6$, pp.765-786.

[12] Daniels, B.W., Booker, Q., (2011), "The effects of audit firm rotation on perceived auditor independence and audit quality", Research in Accounting Regulation, vol.23, pp.78-82.

[13] Dart, E., (2011), “UK investors' perceptions of auditor independence", The British Accounting Review, vol.43, Nº3, pp.173-185.

[14] Gay, G. and Simnett, R. (2003), "Auditing \& Assurance Services in Australia", 2nd ed., McGraw-Hill Book Australia Pty., Sydney.

[15] Goldman, A., \&Barlev, B., (1974), « The Auditor-Firm Conflit of Interests: Its Implications for Independance», The Accounting Review, vol. 49, $\mathrm{N}^{\circ} 4$, pp.707-718

[16] Ghosh, A.,\& Moon, D., (2005), "Auditor Tenure and Perceptions of Audit Quality", The Accounting review, vol.80, $\mathrm{N}^{\circ}$ 2, pp. 585- 612 .

[17] Hamuda,K., \&Sawan, N., (2014), "Perceptions of auditor independence in Libyan Audit Market", International Business Research, vol.7, $\mathrm{N}^{\circ}$ 2,pp.120-128.

[18] Jensen, W., \&Meckling., (1976), “ Theory of the firm: managerial behavior, agency cost and ownership structure", Journal of financial Economics, vol.3, pp.305-360.

[19] Jeong, S. W., Jung K., \& Lee S.J., (2005), "The effect of mandatory auditor assignment and non audit service on audit fees: Evidence from Korea", International Journal of Accounting, vol. 40, N³, pp. 233-248.

[20] Matsumura, E.M., \& Tucker, R.R., (1995), "Second Partner Review: An Analytical model", Journal of Accounting Auditing and Finance, pp. 173-200.

[21] PratDit-Hauret, C., (2003), “ L'indépendanceperçue de l'auditeur", Revue Française de Gestion, vol.29, N¹47, pp. 105-117.

[22] Salehi,M., Mansoury,A., \&Azari,Z., (2009), “Audit Independence and Expectation Gap: Empirical Evidences from Iran", International Journal of Economics and Finance, vol.1, $\mathrm{N}^{\circ} 1, \mathrm{pp} .165-174$.

[23] Wang,X., Davidson,W.,\&Hongxia,W., (2010), "The SarbanesOxley Act and CEO tenure, turnover, and risk aversion". The quarterly review of economics and finance, vol .50, pp. 367-376.

[24] Watts,R.L., \& Zimmerman, J.L., ( 1983), “ Agency problems, Auditing and the theory of the firm: some evidence", Journal of Law and Economics, vol.5, N³, pp.305-329. 